\title{
Detection of virulence gene belonging to cag pathogenicity island in Helicobacter pylori isolates after multiple unsuccessful eradication therapy in Northwest Croatia
}

\section{DIJANA VARDA BRKIĆ1 MIROSLAVA KATIČIĆ2,3 BRANKA BEDENIĆ 1,3 ALEKSANDRA PRESEČKI STANKO ${ }^{1}$ VANDA PLEČKO ${ }^{1,3}$ \\ ${ }^{1}$ Department of Clinical and Molecular Microbiology, University Hospital Centre Zagreb, Kišpatićeva 12, Zagreb \\ 2 University Hospital Merkur, Zajčeva 19, Zagreb \\ ${ }^{3}$ School of Medicine, University of Zagreb, Zagreb, Croatia}

Correspondence:

Dijana Varda Brkić

dijanavb098@gmail.com

Key words: Helicobacter pylori, genotyping, cag pathogenicity island, cagA

Received July 12, 2015

Revised February 19, 2016.

Accepted February 22, 2016.

\begin{abstract}
Background: Some of the genes belonging to cag pathogenicity island (cagPAI) in Helicobacter pylori were found to be associated with an increased severity of gastric mucosal inflammation that might lead to the development of gastroduodenal disease.

Aim: The aim of our study was to define a group of patients based on the frequency of virulence genes of $\mathrm{cag} P A I$ island and comparison with pathohistological alterations of gastric mucosa who need to be subjected to further eradication therapy after previous unsuccessful eradication therapy and in spite of benign endoscopic findings.
\end{abstract}

Material and methods: In total $103 \mathrm{H}$. pylori isolates were analysed. Genes encoding virulence factors were detected by PCR with primers for 10 loci in cagPAI: Apcag (cagA promotor region), cagA1, cagA2, cagA3, cagM, cagT, cagE, LEC, tnpA and tnpB. The patients who provided isolates were classified into three clinical categories: non-ulcer dyspepsia $(n=69)$, erosio/ulcus ventriculi $(n=22)$ and erosiolulcus duodeni $(n=12)$.

Results: 16 strains (15.5\%) were negative for all tested genes. 87 (84.5\%) of the isolates had parcially deleated cagPAI. None of the isolates possessed all 10 genes. The frequency of single cagPAI genes were as follows: Apcag 63.1\%, cagA1 71.8\%, cagA2 69.9\%, cagA3 5.8\%, cagM 71.8\%, cagE 75,7\%, cagT 68\%, tnpA 9.7\%, tnpB 7.8\% $i$ LEC $48.5 \%$.

No statistically significant difference was observed between the presence of any $\mathrm{cag} P A I$ genes and endoscopic diagnosis $(p>0.16)$. The presence of $\mathrm{Cag} \mathrm{A} 2$, Apcag and cagM showed statistically significant correlation with higher level of patohistological parameters of gastritis $(p<0.05)$.

Conclusions: $\mathrm{H}$. pylori isolates with positive cagA, Apcag and cagM genes are correlated to higher degree of patohistological lesions of gastric mucosa; without statistically significant correlation with endoscopic diagnosis.

\section{INTRODUCTION}

any studies have confirmed the role of $H$. pylori in the develop1 ment of chronic gastritis, gastric and duodenal ulcer and the ethiological role in the pathogenesis of gastric carcinoma and mucosaassociated lymphoid tissue (MALT) lymphoma.

H. pylori possess many virulence genes; one of them is cag pathogenicity island (cagPAI) (1). CagPAI is since its discovery the most analysed 
segment of $H$. pylori genome. It is approximately 40 kilobase pairs region of $H$. pylori chromosome and contains around 30 genes divided into region I and II. CagPAI is defined as intact if all genes are present, parcially deleated as presence of several genes and negative (deleated) if there are no genes at all (2). Many studies report correlation between presence of intact cagPAI, partially deleated and deleated cagPAI and clinical outcome. Some authors correlate intact cagPAI with severe gastroduodenal diseases, with higher grade of chronic gastritis and premalignant lesions of gastric mucosa. (1, 3-4), while partially deleated and deleated cagPAI are associated with milder forms of gastroduodenal disease and lower grade of pathological alternations of gastric mucosa $(5-6)$. On the contrary, some of the authors did not find correlation between cagPAI and gastroduodenal disease (7). CagPAI encodes multiple structural components of bacterial type IV secretion system (T4SS). T4SS translocates cagA protein directly to the cytosol of the gastric epitelium where it gets tyrosin phosphorylated by Src-family kinases and becomes able to alter the host cell functions leading to malignant transformation (2).

CagA gene is located in the region I of cagPAI and is considered to be the marker of this region. CagA positive isolates are associated with more severe clinical features in many studies. However, there are contradictory results in the references regarding these studies.

CagE is also located in the region I and is necessary to induce production of interleukin IL-8. Some authors consider cagE gene to be better marker of cagPAI region compared to $c a g A$ and more useful in monitoring the progress of $H$. pylori induced gastric disease. CagT gene is a marker of cagII region and some studies connect it with more severe clinical disease (8). LEC (left terminal end of cagII) is not necessary for translocation of cagA into the host cell or induction of interleukin IL8. It is associated with peptic ulcer and adenocarcinoma. Some of the study found connection of $\operatorname{tnp} A$ gene with peptic ulcer (9).

There are no published studies on the presence of $H$. pylori virulence genes in Croatia. Considering quite large number of patients with multiple unsuccessful eradication therapy, in spite of lack of clinical symptoms and benign endoscopic result, there is a question to pose whether to insist on eradication or not.

The aim of our study was to detect virulence genes of H. pylori just in these patients as a possible predictors of future severe gastroduodenal diseases, by comparing it with clinical and pathohistological results.

\section{MATERIAL AND METHODS}

\section{Patients}

The study analysed gastroscopic test results and bioptic specimens of gastric mucosa with positive $H$. pylori culture in 103 patients examined during routine, clinical gastro- duodenoscopies in the endoscopic laboratory of the University Hospita Merkur in Zagreb during the period 2008.-2012. Microbiological and molecular analysis was performed at the Department for Clinical and Molecular Microbiology of the University Hospital Center in Zagreb and pathohistological testing of the gastric biopsy specimens at the Department for Pathology of University Hospital Merkur. The study was approved by the Ethical Comittee of the University Hospital Center Zagreb and University Hospital Merkur. The patients had signed the informed consent. Twenty-six men and seventy-seven woman in the age range of 28 to 80 years were included in the study. All patients were previously treated with eradication therapy for $H$. pylori. According to the endoscopic finding patients were classified in three groups: non ulcer dyspepsia (NUD), erosio/ulcus ventriculi (EUV), erosio/ulcus duodeni (EUD).

\section{Bacterial culture}

The biopsy specimens (one from corpus and one from antrum) were transported in tioglicolate broth, homogenized and seeded on Columbia agar with addition of $7 \%$ horse blood and Helicobacter pylori Selective Supplement SR 0147E (Oxoid) for cultivation of $H$. plyori. The plates were incubated in microaerophylic atmosphere with $100 \%$ humidity for 3-5 days. Identification was done based on macromorphology, micromorphology and biochemical testing (oxidase, urease, catalase). The strains were stored at $-80^{\circ} \mathrm{C}$ in brucela broth with $10 \%$ glycerol.

\section{DNA extraction}

Extraction of chromosomal DNA was performed with commericial kit: High Pure PCR Template Preparation Kit, Version 16 (Roche Diagnostics Gmbh, Mannheim, Germany) according to the manufacturer's recommendation. The DNA was stored at $-20^{\circ} \mathrm{C}$ until used for molecular studies.

\section{PCR amplification}

PCR was used to detect the following genes: cagAl, cagA2, cagA3, cagE, cagM, cagT, cagA promotor region (Apcag), $\operatorname{tnp} A, \operatorname{tn} p B$ and $L E C$ using primers and conditions shown in Table 1. (10-14). A set of primers P1 and P2 that amplified a $26 \mathrm{kDa}$ antigen $(A g)$ gene present in all strains of $H$. pylori was used as a positive PCR control. All PCR reactions were performed using a GeneAmpC PCR System 9700 (A6B Applied Biosystems. PCR products were visualised by electrophoresis in in $2 \%$ agarose gel, after staining with ethidium bromide and examined in UV transilluminator. A 100 bp DNA ladder (Sigma) was used as a size marker. Reference strains 47164 and 17874 (Culture collection, University of Goethenburg) were used a positive control.

\section{Histology}

Specimens for pathohistological analysis were fixed in a standard $4 \%$ neutral buffered formalin, and cut into 
Table 1. Primers used in this study

\begin{tabular}{|c|c|c|c|c|c|}
\hline Gene & Primer & Primer sequence & Amplicon size & Annealing temp. & Reference \\
\hline \multirow[t]{2}{*}{ cagM } & Cag 5 & ACAAATACAAAAAAGAAAAAGAGGC & $586 \mathrm{bp}$ & $53^{\circ} \mathrm{C}$ & 10 \\
\hline & Cag 6 & ATTTTTCAACAAGTTAGAAAAAGCC & & & \\
\hline \multirow[t]{2}{*}{$\operatorname{tnp} A$} & Cag10 & ATCAGTCCAAAAAGTTTTTTCTTTCC & $344 \mathrm{bp}$ & $53^{\circ} \mathrm{C}$ & 10 \\
\hline & Cag11 & TAAGGGGGTATATTTCAACCAACCG & & & \\
\hline \multirow[t]{2}{*}{$\operatorname{tnp} B$} & Cag 8 & ACAAATACAAAAAAGAAAAAGAGGC & $569 \mathrm{bp}$ & $53{ }^{\circ} \mathrm{C}$ & 10 \\
\hline & Cag 9 & AGCTAGGGAAAAATCTGTCTATGCC & & & \\
\hline \multirow[t]{2}{*}{ cagA2 } & CAG1 & AGACAACTTGAGCGAGAAAG & $320 \mathrm{bp}$ & $53{ }^{\circ} \mathrm{C}$ & 11 \\
\hline & CAG-2 & TATTGGGATTCTTGGAGGCG & & & \\
\hline \multirow[t]{2}{*}{$\operatorname{cag} E$} & CagE-F1 & ACAAATACAAAAAAGAAAAAGAGGC & $329 \mathrm{bp}$ & $52{ }^{\circ} \mathrm{C}$ & 12 \\
\hline & CagE-R1 & GAAGTGGTTAAAAAATCAATGCCCC & & & \\
\hline \multirow[t]{2}{*}{$\operatorname{cag} T$} & CagT-F1 & CCATGTTTATACGCCTGTGT & $301 \mathrm{bp}$ & $52^{\circ} \mathrm{C}$ & 12 \\
\hline & CagT-R1 & CATCACCACACCCTTTTGAT & & & \\
\hline \multirow[t]{2}{*}{ cagA3 } & CagA-F1 & AACAGGACAAGTAGCTAGCC & $701 \mathrm{bp}$ & $52{ }^{\circ} \mathrm{C}$ & 12 \\
\hline & CagA-R1 & TATTAATGCGTGTGTGGCTG & & & \\
\hline \multirow[t]{2}{*}{ cagAl } & CagA-F2 & ACAAATACAAAAAAGAAAAAGAGGC & $349 \mathrm{bp}$ & $52^{\circ} \mathrm{C}$ & 12 \\
\hline & CagA-R2 & CTGCAAAAGATTGTTTGGCAGA & & & \\
\hline \multirow[t]{2}{*}{ Apcag } & CagA-R2 & CTGCAAAAGATTGTTTGGCAGA & $730 \mathrm{bp}$ & $52^{\circ} \mathrm{C}$ & 12 \\
\hline & AP-F1 & GTGGGTAAAAATGTGAATCG & & & \\
\hline \multirow[t]{2}{*}{$L E C$} & LEC-F1 & ACATTTTGGCTAAATAAACGCTG & $320-550 \mathrm{bp}$ & $55^{\circ} \mathrm{C}$ & 13 \\
\hline & LEC-R1 & TCTCCATGTTGCCATTATGCT & & & \\
\hline \multirow[t]{2}{*}{$A g$} & P1 & TGGCGTGTCTATTGACAGCGAGC & $298 \mathrm{bp}$ & $57^{\circ} \mathrm{C}$ & 14 \\
\hline & P2 & CGTGCTGGGCATACTTCACCATG & & & \\
\hline
\end{tabular}

slides. Slides were routinely stained ana analysed according to modified Sydney classification of gastritis (15). Metaplasiae were scored as yes or no, concerning that none of the patients had incomplete metaplasia of II or III grade. All metaplasias were of the I grade.

\section{Statistical analysis}

Age and complex scores were expressed as mean and standard deviation (SD). Comparison for complex scores were done using Student's t-test. Categorical variables were presented as frequencies (\%). The comparison between subgroups for categorical variables were done using $\chi$ test or Fischer exact test with the calculation of odds ration (OR) together with $95 \%$ confidence intervals $(\mathrm{CI})$. Logistic regression analysis was used to calculate OR (95\% CIs) for the association of the presence of individual genes with complex scores (OR was calculated for the 1 -point change in complex score). A P value of $<0.05$ was considered statistically significant for all tests performed. The analysis was performed using STATISTICA, version 10. (StatSoft, Inc., OK, USA).

\section{RESULTS}

In the study were included 103 patients: 25 men and 78 woman in the age range of 28 to 81 years, with median age of 55.8 years $(\mathrm{SD} \pm 11.8)$. According to endoscopic results patients were classified into three groups: 68 (66\%) with non-ulcer dyspepsia (NUD), 22 (21.4\%) with erosio/ulcus ventriculi (EUV), and 13 (12.6\%) with erosio/ulcus duodeni (EUD).

Out of $103 \mathrm{H}$. pylori isolates 16 (15.5\%) had deleated cagPAI, and 87 (84.5\%) partially deleated cagPAI. None of the isolates had intact cagPAI. There was no statistically significant difference in the distribution of cagPAI either according to the gender $(\chi 2=0.005, \mathrm{df}=1, \mathrm{p}=0.941)$ or according th the endoscopic diagnosis $(\chi 2=1.142 \mathrm{df}=2$, $\mathrm{p}=0.565)$ as shown in Table 2 .

The frequency of particular genes was as follows: cagA1 $71.8 \%$, cagA2 69.9\%, cagA3 5.8\%, cagE 75.7\%, cagM $71.8 \%$, tnp A 9.7\%, cagT 68\%, Apcag 63.1\%, LEC $48.5 \%$ and $\operatorname{tnp} B 7.8 \%$ as shown in Figure 1. 


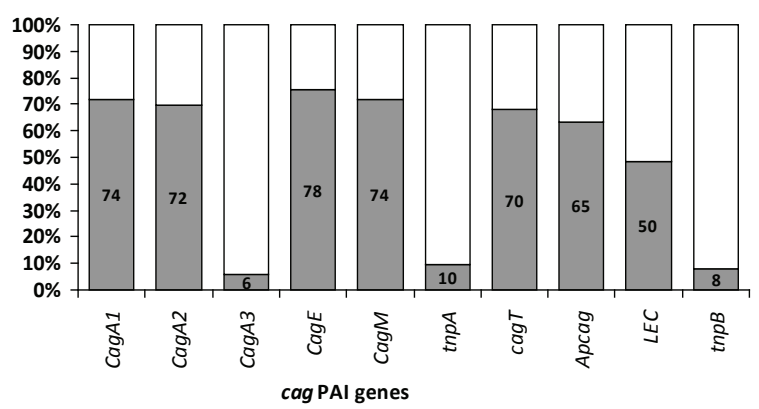

Figure 1. Percentage and number of positive cagPAI genes from $\mathrm{H}$. pylori isolates $(N=103)$

Table 2. Correlation of cagPAI and endoscopic diagnosis

\begin{tabular}{|lcc|}
\hline $\begin{array}{l}\text { Endoscopic } \\
\text { diagnosis }\end{array}$ & $\begin{array}{c}\text { Partialy deleted } \\
\text { cagPAI }\end{array}$ & $\begin{array}{c}\text { Completely deleted } \\
\text { cagPAI }\end{array}$ \\
\hline EUV 22 (21.4\%) & $17(77.3 \%)$ & $5(22.7 \%)$ \\
EUD 13(12.6\%) & $11(84.6 \%)$ & $2(15.4 \%)$ \\
NUD 68 (66.0\%) & $59(86.8 \%)$ & $9(13.2 \%)$ \\
\hline
\end{tabular}

EUV - erosio/ulcus ventriculi; EUD - erosio/ulcus duodeni; NUD non-ulcer dyspepsia.

Pathohistological analysis of antrum revealed inflammation in all patients (100\%), activity was found in $66 \%$ of the patients, atrophy in $6.8 \%$ and intestinal metaplasia in $24.3 \%$. All patients had inflammation in the corpus. Activity was found in $62.2 \%$ of the patients. Atrophy was present in $4.9 \%$ and metaplasia in $13.6 \%$ of the patients. Table 3. shows the distribution of different grades of pathohistological parameters of gastritis in the antrum and corpus.

There was no statistically significant difference in pathohistological lesions between the patients with parcially deleated cagPAI and those with deleated cagPAI ( $p>0.05$ for all parameters describing pathohistological lesions).

The presence of CagA2 was significantly related to the higher grade of inflammation of antrum $(\chi 2=6.872, \mathrm{df}=2$, $\mathrm{p}=0.032$ ), with increased density of $H$. pylor in the corpus $(\chi 2=16.7, \mathrm{df}=3, \mathrm{p}=0.001)$, and with higher total score for the corpus (mean $\pm \mathrm{SD}=4.1 \pm 1.5$ for CagA2+, $3.3 \pm 1.4$ for CagA2, $\mathrm{t}=2.687, \mathrm{p}=0.008)$ as shown in Table 4 .

The presence of Apcag was significantly correlated with higher inflammatory score of antrum (Apcag+:mean \pm $\mathrm{SD}=4.9 \pm 1.7 ;$ Apcag-: 4.0 $\pm 1.7 ; \mathrm{t}=2.332, \mathrm{p}=0.022$ ) (Table 4).

The presence of $c a g M$ was related to the higher densitiy of $H$. pylori in the corpus $(\chi 2=9.864, \mathrm{df}=3, \mathrm{p}=0.020)$. and higher total score for the corpus (CagM+: mean $\pm \mathrm{SD}=4.1 \pm 1.6 ;$ CagM-: $3.4 \pm 1.4 ; \mathrm{t}=2.021, \mathrm{p}=0.046$ ) (Table 4).
Table 3. Pathohistological characteristics of the patients $(n=103)^{*}$

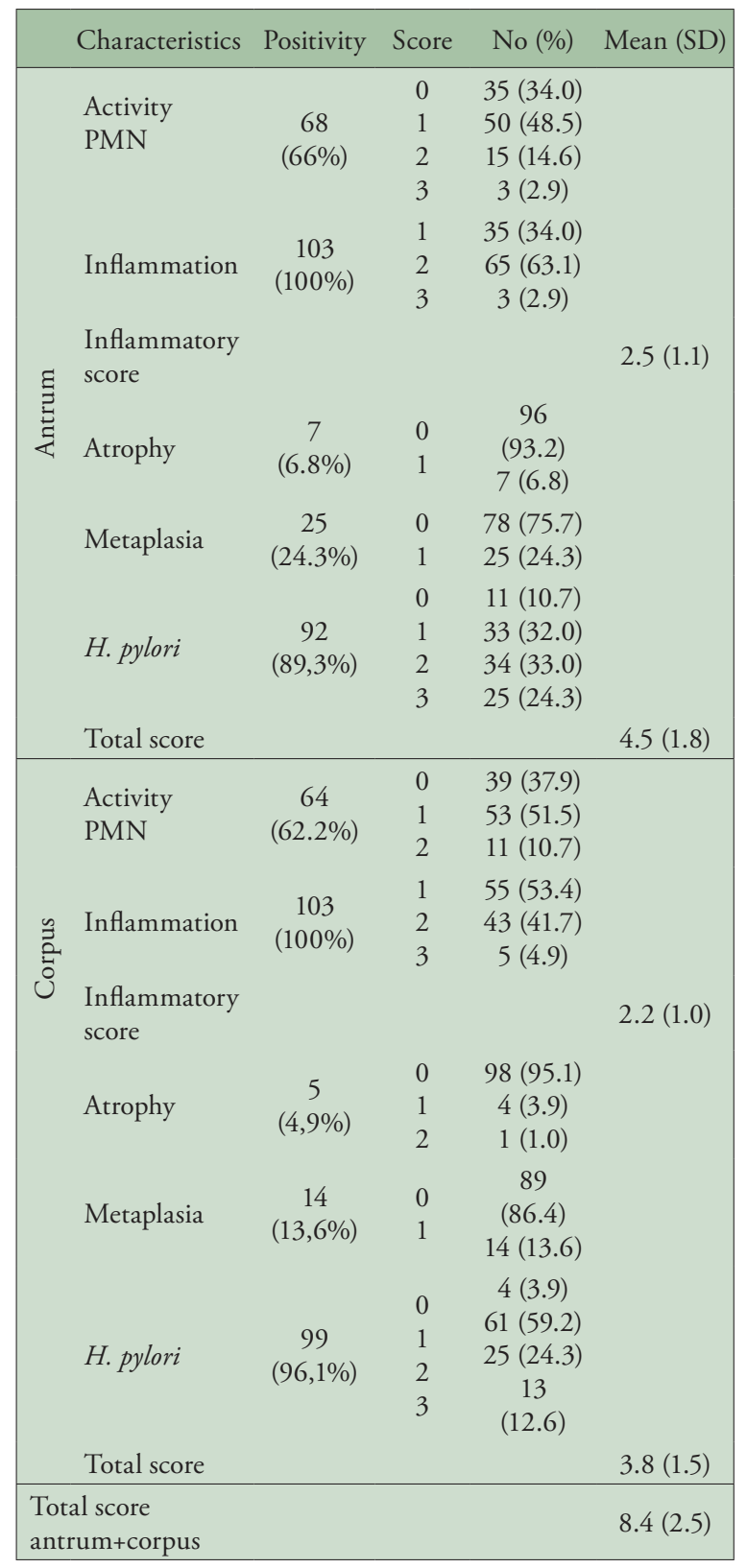

*Accoridng to the Updated Sydney system classification with metaplasia absent $=0$ and present $=1, \mathrm{PMN}=$ Polymorph-nuclear cells

The presence of cagT and $L E C$ was related to less frequency of antrum atrophy (cagT, $\chi 2=5.35, \mathrm{df}=1, \mathrm{p}=0.021$ ).

Correlation between any of ten cagPAI genes and endoscopic diagnosis ( $p>0.16$ for all) was not found in this study.

\section{DISCUSSION}

In our study, we amplified $10 \mathrm{H}$. pylori genes in order to characterize cagPAI. Intact cagPAI was not found but there was $84.5 \%$ parcially deleated, and $15.5 \%$ completely 
Table 4. Association of H. pylori cagPAI genes with pathohistological changes of gastric mucosa

\begin{tabular}{|c|c|c|c|c|c|c|}
\hline \multicolumn{7}{|l|}{ Pathohistology } \\
\hline & Grade & Negative & Positive & Statistics & P-value & OR $(95 \% \mathrm{CI})$ \\
\hline \multicolumn{7}{|l|}{$\operatorname{cag} A 2$} \\
\hline Inflammation, antrum & $\begin{array}{l}1 \\
2 \\
3\end{array}$ & $\begin{array}{c}16 \\
15 \\
0\end{array}$ & $\begin{array}{c}19 \\
50 \\
3\end{array}$ & $\chi^{2}=6.872$ & 0.032 & $\begin{array}{c}2.941(1.216-7.217) \\
\text { for grade } 1 \text { vs. } 2 / 3\end{array}$ \\
\hline H. pylori, corpus & $\begin{array}{l}0 \\
1 \\
2 \\
3\end{array}$ & $\begin{array}{c}3 \\
25 \\
1 \\
2\end{array}$ & $\begin{array}{c}1 \\
36 \\
24 \\
11\end{array}$ & $\chi 2=16.700$ & 0.001 & $\begin{array}{l}15.02(4.558-67.12) \\
\text { for grade } 0 / 1 \text { vs. } 2 / 3\end{array}$ \\
\hline $\begin{array}{l}\text { Total score, corpus } \\
\text { CagM }\end{array}$ & Mean \pm SD & $3.3 \pm 1.4$ & $4.1 \pm 1.5$ & $\mathrm{t}=2.687$ & 0.008 & $3.841(1.531-9.638)$ \\
\hline H. pylori, corpus & $\begin{array}{l}0 \\
1 \\
2 \\
3\end{array}$ & $\begin{array}{c}1 \\
24 \\
2 \\
2\end{array}$ & $\begin{array}{c}3 \\
37 \\
23 \\
11\end{array}$ & $\chi 2=9.864$ & 0.020 & $\begin{array}{l}8.665(2.621-38.73) \\
\text { for grade } 0 / 1 \text { vs. } 2 / 3\end{array}$ \\
\hline $\begin{array}{l}\text { Total score, corpus } \\
\text { cagT }\end{array}$ & Mean \pm SD & $3.4 \pm 1.4$ & $4.1 \pm 1.6$ & $\mathrm{t}=2.021$ & 0.046 & $3.259(1.293-8.215)$ \\
\hline Atrophy, antrum & $\begin{array}{l}0 \\
1\end{array}$ & $\begin{array}{c}28 \\
5\end{array}$ & $\begin{array}{c}68 \\
2\end{array}$ & $\chi 2=5.352$ & 0.021 & $0.165(0.030-0.918)$ \\
\hline Apcag & & & & & & \\
\hline Inflammatory score, antrum & Mean \pm SD & $2.2 \pm 1.0$ & $2.7 \pm 1.1$ & $\mathrm{t}=2.283$ & 0.025 & $2.448(1.285-26.008)$ \\
\hline $\begin{array}{l}\text { Total score, antrum } \\
L E C\end{array}$ & Mean \pm SD & $4.0 \pm 1.7$ & $4.9 \pm 1.7$ & $\mathrm{t}=2.332$ & 0.022 & $2.349(1.027-5.374)$ \\
\hline Atrophy, antrum & $\begin{array}{l}0 \\
1\end{array}$ & $\begin{array}{l}46 \\
7\end{array}$ & $\begin{array}{c}50 \\
0\end{array}$ & & $0.016^{*}$ & $0(0-0.524)$ \\
\hline
\end{tabular}

deleated. In contrast, in the study done in Mexico which included 11 genes, there was $90 \%$ of intact cagPAI, $4 \%$ of parcially delated and $6 \%$ of completely deleated (16).

We want to emphasise that there is disconcordance between different studies in the number of cagPAI genes analysed, and the definition of intact, deleated and parcially deleated cagPAI. Most studies analysed limited number of genes. Salih et al. analyzed 4 genes of cagPAI and reported $42.1 \%$ of intact, $39.5 \%$ of partially deleated and $18.4 \%$ completely deleated cagPAI and the correlation of intact cagPAI and duodenal ulcer (17). Baghaei et al. analyzed three genes and reported $17 \%$ of intact cagPAI, $62 \%$ of partially deleated and $20 \%$ of completely deleated in Iran population (8). Nygen et al. analysed 30 genes with the same number of strains and similar endoscopic diagnosis as in our study and found $88 \%$ of intact, and $12 \%$ of parcially deleated in Vietnam population (18). Based on bibliographical data it is evident that the frequency of intact cagPAI varies depending on the geographic area.

Results of our study did not demonstrate any correlation between deleated and partially deleated cagPAI and either endoscopic diagnosis or pathohistological lesions. It is hard to explain wheter our results reflect the situation in our geographic region or if they are related to a specific category of patients with predominant non-ulcer dyspepsia. The study from Maeda et al. from Japan confirmed our observation that partially deleated cagPAI is associated with non-ulcer dyspepsia in contrast with intact cagPAI found in patients with gastric cancer (19). We do not have the data for different categories of patients with other grades of gastroduodenal disease. This is the first study of genotyping of cagPAI in Croatia. The future studies should be focused on genotyping of cagPAI in Croatian patients with severe gastroduodenal disease.

CagA is considered to be a marker of cagPAI region (20). In our study we analysed three different segment of cagA gene. cagA1 segment close to the promoter region, middle segment cagA2 and right end cagA3. While the rate of cagA 1 and cagA2 positivity was similar $(71.8 \%)$ and (69.9\%) respectively, the frequency of $c a g A 3$ was low (5.8\%). The frequent deletion of cagA3 compared to cagAI and cagA 2 in the control strains reported by Matar et al. was attributed to decreases pathogenicity (9). Prevalence of cagA positive strains differs between the countries and is the highest in East Asia (90\%), Japan (100\%) (21) and Bulgaria (84.9\%) (22). The moderate prevalence was found in Iran (62\%) (23), Slovenia (61\%) (24), Columbia (64\%) (21), Turkey (49\%) (25), Equador (46\%) (26) and Portugal (31.8\%) (27). The previous studies on $H$. pylori in Croatia reported the prevalence of serum antibodies 
against bacterial virulence antigens p120 (CagA- cytotoxin associated antigen) of $91.3 \%$ in the group of patients with severe gastroduodenal diseases (28). In our study the prevalence of cagA was not statistically significantly correlated with clinical diagnosis which is in concordance with the study of Strauss et al. (81\% positive) (29) but different from the study of Marie $\mathrm{M}$ et al. (62\% positive) where the presence of $c a g A$ was correlated with gastritis and peptic ulcer (30). In our study the presence of cagA was correlated with higher degree of inflammation in the gastric mucosa, particularly in antrum $(\mathrm{p}=0.001)$. In the previous study from Croatia p120 (cagA) seropositivity was significantly more often present in patients with higher activity grade in the antrum (28). These results are in concordance with other studies which proved that cagA enhances accumulation of neutrophiles, determined as inflammatory score and according to some studies induces the production of interleukine IL-8 (17). These results are confirmed by studies from Iran (31). No correlation between cagA and $\operatorname{cag} E$ and clinical outcome in Iran patients was found (32). In our study cagA2 is related to the higher density of $H$. pylori $(\mathrm{p}=0.001)$ and this correlation was confirmed by other authors (33-35). However, some studies did not find any significant relationship between cagA positivity and $H$. pylori density, neutrophil activity, lymphoid aggregation in lamina propria and glandular atrophy in the biopsies, but significant association was detected with severe chronic gastritis (23). The frequency of $c a g E$ in our study was higher than of cagA $(75.7 \%$ vs $71.8 \%)$. This is in agreement with some studies which consider $c a g E$ to be a better marker of $c a g \mathrm{I}$ region than $\operatorname{cag} A(9,36)$. We did not find any association between $\operatorname{cag} E$ and endoscopic diagnosis and pathohistological lesions which is in agreement with the results from a study conducted in Portugal where cagE is more prevalent than cagA (27). Modena at al. have not found association between $c a g E$ and clinical outcome (37), contrarily to the studies which described higher frequency of $c a g E$ and sever gastroduodenal disease such as ulcer and gastric cancer, than in gastritis (3). CagT as a marker of cagII region was identified in $68 \%$ of our isolates and was associated with decreased frequency of antrum atrophy without any correlation with clinical diagnosis. However, some authors did not report correlation with either clinical diagnosis or pathohistological alterations of gastric mucosa (8). Mattar et al. reported that $98 \%$ of the patients with ulcer disease retained cagT gene (9), while the isolates with deleted cagT were more frequent in the patients with chronic gastritis compared with peptic ulcer disease or gastric cancer in Japanese population (12). Fisher et al. claim that the patients with $H$. pylori lacking cagT have disfunctional T4SS and are unable to translocate cagA protein into the host cell (38). In the study from England the majority of ulcer disease strains retained the cagT and cagE gene (39). In our study cagM with the prevalence of $71.8 \%$ was associated with increased density of $H$. pylori in corpus and higher total score for cor- pus, but unrelated to the endoscopic diagnosis. Matar et al. correlated this gene with higher grade of gastritis and peptic ulcer disease (9). LEC (left end of cagII) was found in $48.5 \%$ of our isolates and was related to the lower prevalence of antrum atrophy. The $L E C$ is rearranged more frequently in isolates linked to severe pathology (40).

This study comprised the patients without successfull eradication of $H$. pylori infection after multiple antibiotic courses in spite of the fact that antimicrobial therapy was after one or two unsuccessful therapeutic outcomes created in accordance with antimicrobial susceptibility testing.

The most patients had normal or harmless endoscopic result (non-ulcer dispepsia). Although pathological alterations did not point out to the danger of premalignant lesions our study found a high frequency of cagA, ApCag, cagT and $\operatorname{cag} M$ genes in the isolates recovered from the patients included in the study. The correlation between the presence of these genes and higher degree of serious pathohistological lesions in gastric mucosa was observed. According the the results of the present study it could be concluded that the presence of these genes can predispone for the development of ulcer, premalignant or malignant diseases. Thus, insisting on eradication of $H$. pylori in spite of harmless endoscopis and histological results should be considered as the only correct choice.

In spite of the fact that application of molecular diagnostics in detection of virulence genes is too expensive and not recommended for routine diagnostic, it should have a role in selected patients with unsuccessful eradication therapy with usual therapeutic protocols.

Moreover, the genomic profiles generated in this study may be useful for interlaboratory comparisons and are suitable for storage in epidemiological databases for comparative analyses. Our study has been focused on a specific group of patients isolates and may be representative for isolates from patients in this geographic region in Croatia. Future studies are needed to involve other disease specific strain group with appropriate controls.

\section{CONFLICT OF INTEREST}

There is no conflict of interest

\section{FUNDING}

The study was supported by the project of Croatian Ministry of Science, Sport and Education: Helicobacter pylori infection-evolution and new therapeutic approach; number: 108-000000-3114.

\section{REFERENCES}

1. CONTRERAS M, ABRANTE L, SALAZAR V, REYES N, GARCIA-AMADO MA, FERNANDEZ-DELGADO M, ROMERO R, ROJAS H, MICHELANGELI F 2014 Heterogene- 
ity of cag genotypes of Helicobacter pylori in the esophageal mucosa of dyspeptic patients and its relation to histopatthological outcomes. Int J of Inf Dis 26:91-95

http://dx.doi.org/10.1016/j.ijid.2014.03.1387

2. LAI CH, PERNG CL, LAN KH, LIN HJ 2013 Association of IS605 and cag-PAI of Helicobacter pylori Isolated from Patients with Gastrointestinal Diseases in Taiwan. Gastroenterology Research and Practise ID 356217:1-5 http://dx.doi.org/10.1155/2013/356217

3. LIMA VP, DE LIMA MA, FERREIRA MV, BAROS MA, RABENHORST SH 2010 The relationship between Helicobacter pylori genes cagE and virB11 and gastric cancer. Int J Infect Dis 14:613-7 http://dx.doi.org/10.1016/j.ijid.2009.09.006

4. BLASER MJ 2012 Heterogenicity of Helicobacter pylori. Eur J Gastroenterol Hepatol 9:53-7

http://dx.doi.org/10.1097/00042737-201204001-00002

5. CENSINI S, LANGE C, XIANG Z, CRABTREE JE, GHIARA P, BORODOVSKY M, RAPPUOLI R, COVACCI A 1996 Cag A pathogenicity island of Helicobacter pylori, encodes type I-specific and disease-associated virulence factors. Proc Natl Acad Sci USA 93:14648-14653 http://dx.doi.org/10.1073/pnas.93.25.14648

6. XU X, LIU Z, FANG M, YU H, LIANG X, LIX, LIU X, CHEN C, JIA J 2012 Helicobacter pylori CagA induces ornithine decarboxylase upregulation via Src/MEK/ERK/c-Myc pathway: implication for progression of gastric diseases. Exp. Biol. Med 237:435-41 http://dx.doi.org/10.1258/ebm.2011.011199

7. RAJASHREE P. SANTANU C, RONITA D, SIMANTI D, ABHIJIT C, RAMAMURTHYT, BALAKRISH N, DOUGLAS B, MUKHOPADHYAY A. K 2011 Intact cag pathogenicity island of Helicobacter pylori without disease association in Kolkata, India. Int. Med. Microbiol 301(4): 293-302

8. BAGHAEI K, SHOKRZADEH L, JAFARI F, DABIRI H,YAMAOKA Y, BOLFION M, ZOJAJI H, ASLANI M, ZALI REZA M 2009 Determination of Helicobacter pylori virulence by analysis of the cag pathogenicity island isolates from Iranian population. Dig. Liver Dis 41(9):634-638

http://dx.doi.org/10.1016/j.dld.2009.01.010

9. MATTAR R, MARQUES SB, MONTEIRO MS, DOS SANTOS AF, IRIYA K, CARRILHO FJ 2007 Helicobacter pylori cag pathogenicity island genes: clinical relevance for peptic ulcer disease development in Brazil 56:9-14

10. KIDD M, LASTOVICA AJ, ATHERTON JC, LOUW JA 2001 Conservation of the $c a g$ pathogenicity island is associated with vacA alleles and gastroduodenal disease in South African Helicobacter pylori isolates. Gut 49:11-17 http://dx.doi.org/10.1136/gut.49.1.11

11. COVACCI A, CENSINI S, BUGNOLI M, PETRACA R, BURRONI D, MACHIA D, MASSONE A, PAPINI E, XIANG Z, FIGURA N 1993 Molecular characterization of the 128-kDa immunodominant antigen of Helicobacter pylori associated with cytotoxicity and duodenal ulcer. Proc Natl Acad Sci USA 90(12): 5791-5795 http://dx.doi.org/10.1073/pnas.90.12.5791

12. IKENOUE T, MAEDA $S$, GURA K, AKANUMA M, MITSUNO Y, IMAI Y, YOSHIDA H, SHIRATORI Y, OMATA M 2001 Determination of Helicobacter pylori virulence by simple gene analysis of the cag pathogenicity island. Clin Diagn Lab Immunol 8:181-186 http://dx.doi.org/10.1128/cdli.8.1.181-186.2001

13. AKOPYANTS NS, CLIFTON SW, KERSULYTE D, CRABTREE JE, YOUREE BE, REECE CA, BUKANOV NO, DRAZEK ES, ROE BA, BERG DE 1998 Analyses of the cag pathogenicity island of Helicobacter pylori. Mol Microbiol 28:3753 http://dx.doi.org/10.1046/j.1365-2958.1998.00770.x

14. HAMMAR M, TYSZKIEWICZ T, WADSTROM T, OTOLE PW 1992 Rapid detection of Helicobacter pylori in gastric biopsy material by polimerase chain reaction. J Clin Microbiol 30:54-58
15. DIXON MF, GENTA RM, YARDLEY JH, CORREA P 1996 Classification and grading of gastritis. The update Sydney System. International workshop on the Histopathology of Gastritis, Huston 1994. Am J of Surg Pathology 20(10):1161-1181 http://dx.doi.org/10.1097/00000478-199610000-00001

16. ANTONIO-RINCON F, LOPEZ-VIDAL Y, CASTILLO-ROJAS G, LAZCANO-PONCE E, PONCE DE-LEON S, TABCHE-BARRERA M, AGUILAR GUTIERREZ G 2011 Pathogenicity island $c a g, v a c A$ and IS605 genotypes in Mexican strains of Helicobacter pylori associated with peptic ulcers. Annals of Clinical Mycrobiology and Antimicrobials 10:18 http://dx.doi.org/10.1186/1476-0711-10-18

17. SALIH BA, GUNER A, KARADEMIR A,USLU M, OVALI MA, YAZICI D, BOLEK BK, ARIKAN S 2014 Evaluation of the effect of cagPAI genes of Helicobacter pylori on AGS epithelial cell morphology and IL-8 secretion. Antonie van Leeuwenhoek 105:179189 http://dx.doi.org/10.1007/s10482-013-0064-5

18. NGUYEN LT, UCHIDA T, TSUKAMOTO Y, TRINH TD, TA L, MAI HB, LE HS, HO DQ, HOANG HH, MATSUHISA T, OKIMOTO T, KODAMA M, MURAKAMI K, FUJIOKA T, YAMAOKA Y, MORIYAMA M 2010 Clinical relevance of $c a g$ PAI intactness in Helicobacter pylori isolates from Vietnam. Eur J Clin Microbiol Infect Dis 29(6):651-660

http://dx.doi.org/10.1007/s10096-010-0909-z

19. MAEDA $S$, YOSHIDA H, IKENOUE T, OGURA K, KANAI F, KATO N, SHIRATORI Y, OMATA M 1999 Structure of $c a g$ pathogenicity island in Japanese Helicobacter pylori isolates. Gut 44:336-341 http://dx.doi.org/10.1136/gut.44.3.336

20. SOUOD N, KARGAR M, DOOSTI A, RANJBAR R, SARSHAR M 2013 Genetic Analysis of cagA and vacA genes in Helicobacter pylori isolates and their relationship with gastroduodenal diseases in the west of Iran. Iran Red Crescent Med J 15(5):371375 http://dx.doi.org/10.5812/ircmj.3732

21. WATADA M, SHIOTA S, MATSUNARI O, SUZUKI R, MURAKAMI K, FUJIOKA T, YAMAOKA Y 2011 Association betwen Helicobacter pylori cagA-related genes and clinical outcomes in Columbia and Japan. BMC Gastroenterol 11:5685-5692 http://dx.doi.org/10.1186/1471-230X-11-141

22. BOYANOVA L, YORDANOV D, GERGOVA G, MARKOVSKA R, MITOV I 2011 Benefits of Helicobacter pylori cagE genotyping in addition to cagA genotyping: a Bulgarian study. Antonie Van Leeuwenhoek 100:529-535 http://dx.doi.org/10.1007/s10482-011-9608-8

23. VAZIRI F, PEERAYEH S, ALEBOUYEH M, MIRZAEI T, YAMAOKA Y, MOLAEI M, MAGHSOUDI N, ZALI MR 2013 Diversity of Helicobacter pylori genotypes in Iranian patients with different gastroduodenal disorders. World J Gastroenterol 19(34):5685-5692 http://dx.doi.org/10.3748/wjg.v19.i34.5685

24. HOMAN M, LUŽAR B, KOCIJAN BJ, OREL R, MOCILNIK T, SHRESTHA M, KVEDER M, POLJAK M 2009 Prevalence and clinical relevance of cagA, vacA, and iceA genotypes of Helicobacter_pylori isolated from Slovenian children. M J Pedijatr Gastroenterol Nutr 49(3):289-96

http://dx.doi.org/10.1097/MPG.0b013e31818f09f2

25. CHUNG C, OLIVARES A, TORRES E, YILMAZ O, COHEN H, PEREZ-PEREZ G 2010 Diversity of VacA Intermediate Region among Helicobacter pylori Strains from Several Regions of the World. J Clin Microbiol 48:690-696 http://dx.doi.org/10.1128/JCM.01815-09

26. SASAKI T, HIRAI I, IZURIETA R, KWA BH, ESTEVEZ E, SALDANA A, CALZADA J, FUJIMOTO S, YAMAMOTO Y 2009 Analisis of Helicobacter pylori Genotype in Stool Specimens of Asymptomatic People. Lab Med 40:412-414 http://dx.doi.org/10.1309/LMZ2WWCD2A9MFTNW

27. ALMEIDA N, DONATO MM, ROMAOZINHO JM, LUXO C, CARDOSO O, CIPRIANO MA, MARINHO C, FER- 
NANDES A, CARLOS S 2015 Correlation of Helicobacter pylori Genotypes with Gastric Histopathology in the Central Region of a South-European Country. Dig Dis Sci 60:74-85 http://dx.doi.org/10.1007/s10620-014-3319-8

28. FILIPEC-KANIŽAJT, KATIČIĆM, PRESEČKIS, GAŠPAROV S, COLIĆ CVRLJE V, KOLARIĆ B, MRZLJAK A 2009 Serum Antibodies Positivity to 12 Helicobacter pylori Virulence Antigens in Patients with Benign or Malignant Gastroduodenal DiseasesCross- sectional Study. Croat Med 50: 124-132 http://dx.doi.org/10.3325/cmj.2009.50.124

29. STRAUS EW, PATEL H, CHANG J, GUPTA RM, SOTTILE V, SCIRICA J, TARABAV G, IVER S, SAMUEL S, RAFFANIELLO RD 2002 H. pylori Infection and Genotyping in Patients Undergoing Upper Endoscopy at Inner City Hospitals. Dig Dis Sci 47(7):1575-1581 http://dx.doi.org/10.1023/A:1015827404901

30. MARIE MAM 2012 Relationship between Helicobacter pylori Virulence Genes and Clinical Outcomes in Saudi Patients. J Korean Med Sci 27:190-193

http://dx.doi.org/10.3346/jkms.2012.27.2.190

31. HOSSEINI E, POURSINA F,VAN DE WIELE T, GHASEMIAN SAFAEI H, ADIBI P 2012 Helicobacter pylori in Iran: A sistematic review on the association of genotypes and gastroduodenal diseases. J Res Med Sci 17(3):280-292

32. DABIRI H, BOLFION M, MIRSALEHIAN A, REZADEHBASHI M, JAFARI F, SHOKRZADEH L, SAHEBEKHTIARI N, ZOJAJI H, YAMAOKA Y, MIRSATTARI D, ZALI MR 2010 Analysis of Helicobacter pylori genotypes in Afghani and Iranian isolates. Pol J Microbiol 59: 61-66

33. SALIMZADEH L,BAGHERI N, ZAMANZAD B, AZADEGAN-DEHKORDI F, RAHIMIAN G, HASHEMZADEHCHALESHTORI M, RAFIEIAN-KOPAEI M, SANEI MH, SHIRZAD H 2015 Frequency of virulence factors in Helicobacter pylori-infected patients with gastritis. Microb Pathog 80:67-72 http://dx.doi.org/10.1016/j.micpath.2015.01.008

34. BELDA S, SAEZ J, SANTIBANEZ M, RODRIGUEZ JC, SOLA-VERA J, RUIZ-GARCÍA M, BROTONS A, LÓPEZ-GIRONA E, PÉREZ E, SILLERO C, ROYO G 2012 Relationship be- tween bacterial load, morbidity and cagA gene in patients infected by Helicobacter pylori. Clin Microb Infect 18:251-253 http://dx.doi.org/10.1111/j.1469-0691.2012.03884.x

35. ATHERTON JC, THAM K, PEEK RM JR., COVER TL, BLASER MJ 1996 Density of Helicobacter pylori Infection in Vivo as Assessed by Quantitative Culture and Hystology. J Inf Diseases 174(3):552-556

36. BACKERT S, SCHWARZ T, MIEHLKE S, KIRSCH C, SOMMER C, KWOK T, GERHARD M, GOEBEL UB, LEHN N, KOENIG W, MEYER TF 2004 Functional analysis of the cag pathogenicity island in Helicobacter pylori isolates from patients with gastritis, peptic ulcer and gastric cancer. Infect Immun 72(2): 1043-1056 http://dx.doi.org/10.1128/IAI.72.2.1043-1056.2004

37. MODENA P, SALES L, ACRANI G, RUSSO R, VILELA RIBEIRO MA, FUKUHARA Y, DA SILVEIRA WD, MÓDENA JL, DE OLIVEIRA RB, BROCCHI M 2007 Association between Helicobacter pylori genotypes and gastric disorders in relation to the cag pathogeniciti island. Diagn Microbiolol Infect Dis 59(1):7-16 http://dx.doi.org/10.1016/j.diagmicrobio.2007.03.019

38. FISCHER W, PULS J, BUHRDORF R, GEBERT B, ODENBREIT S, HAAS R 2001 Systematic mutagenesis of the Helicobacter pylori cag pathpgenicity island: essential genes for CagA translocation in host cells and induction of interleukin-8. Mol. Microbiol 42(5): $1337-48$ http://dx.doi.org/10.1046/j.1365-2958.2001.02714.x

39. KAUSER F, HUSSAIN MA, AHMED I, SRINIVAS S, DEVI SM, MAJEED AA, RAO KR, KHAN AA, SECHI LA, AHMED N 2005 Comparative genomics of Helicobacter pylori isolates recovered from ulcer disease patients in England. BMC Microbiology 5:32 http://dx.doi.org/10.1186/1471-2180-5-32

40. KAUSER F, KHAN AA, HUSSAIN MA, CARROLI IM, AHMAD N, TIWARI S, SHOUCHE Y, DAS B, ALAM M, ALI SM, HABIBULLAH CM, SIERRA R, MEGRAUD F, SECHI LA, AHMED N 2004 The cag pathogenicity island of Helicobacter pylori is disrupted in the majority of patient isolates from different human population. J Clin Microbiol 40(11):5302-5308 http://dx.doi.org/10.1128/JCM.42.11.5302-5308.2004 